\title{
A Case Study on Comparison of Column Reinforcement with Couplers and without Couplers as Lap Splices
}

\author{
N. Ramanjaneyulu ${ }^{1}$ and K. Aparna ${ }^{2}$ \\ ${ }^{1}$ Asst. Professor, CVR College of Engineering/Civil Engg. Department, Hyderabad, India \\ Email: rams.613@gmail.com \\ ${ }^{2}$ Asst. Professor, CVR College of Engineering/Civil Engg. Department, Hyderabad, India \\ Email: aparnaraokatta@gmail.com
}

\begin{abstract}
Regular construction practices focus makes use of reinforcing bars for transferring forces. Method of lap Splice is generally used for ensuring continuity of reinforcement steel. However, this method results in minor defects such as joint failure, inadequate length for lapping, improper welding of bars, increased cost of labor etc.

A comparative study of column reinforcement with couplers and without couplers as lap splices was carried out through a case study of an under construction building. Initially the quantity of reinforcing bars required for conventional lap splicing of columns was estimated. The value of steel for providing lap splices within the columns was also determined. Finite element analysis of coupled rebar is carried out to check for the yielding and ultimate stresses developed. These values are verified with that specified in the code. The use of couplers significantly decreases construction time and quantity of steel required in lapping.

The use of couplers as lap splices provides an economic way of connecting reinforcement without adversely affecting the strength of the joint.
\end{abstract}

Index Terms: Conventional lap spicing, reinforcement couplers, threading, Joints, Columns, FEA.

\section{INTRODUCTION}

Lapping or splicing of reinforcement means when two reinforcement bars overlap over one another to ensure continuity of bar for a given span. Several factors affect the selection of lap length such as grade of concrete and rebar, size of reinforcement bar etc. Lapping of reinforcement bars has several limitations such as, different structural elements require different lapping lengths, congestion in reinforcement resulting in improper concreting of concrete members, lack of proper supervision while lapping may result in failure of joint.

Splicing of reinforcement adopted in regular structures are replaced by using mechanical couplers. these mechanical couplers are also used in reinforced columns, beams, slabs and various other structural elements. The use of mechanical coupler requires early preparation of reinforcement bar which involves threading of reinforcement bar followed by enclosing with a coupler sleeve. We need to ensure threading of bar is done in the direction of installation.

Some sizes of reinforcing bars necessitate an increase in length of lap. This results in difficulty of placing and compaction of concrete. The use of rebar couplers facilitates in reducing congestion caused due to increased length of lap. The coupler mechanism is applied to bars of same diameter where at the point of joint one bar is fixed firmly with coupler sleeve and another bar is free to rotate and move.

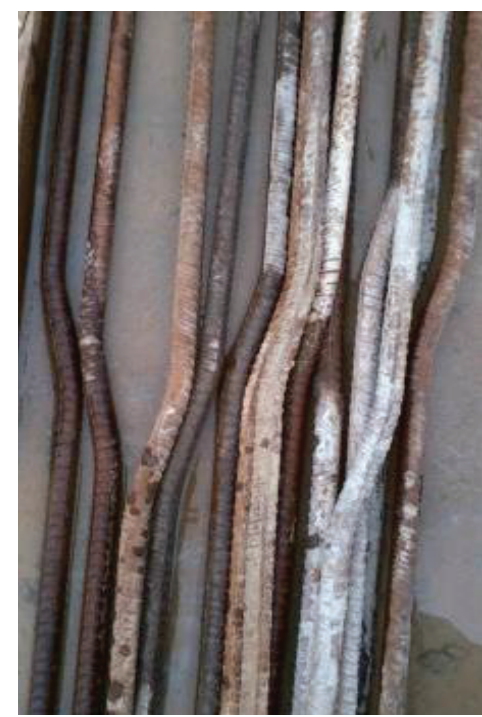

Figure 1. Profile of Rebar for lap splice

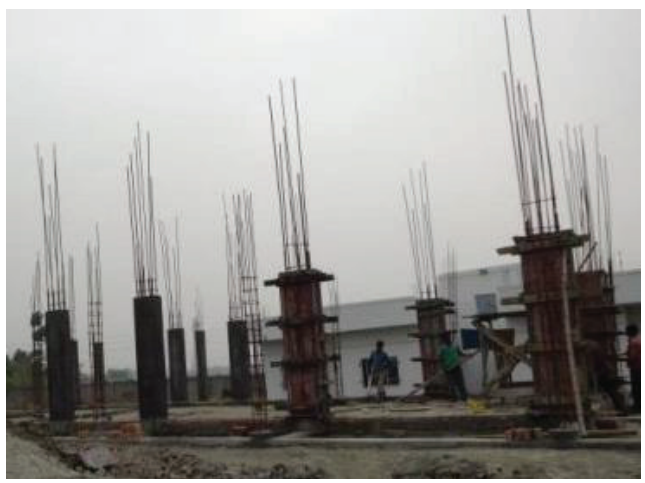

Figure 2. Traditional rebar extension for further lapping/splicing

According to Indian standard code of practice for plain and reinforced concrete structures clause 26.5.3, at the location of splice, it requires the rebar to be bent at an inclination not exceeding a slope value of 1 in 6 from the axis of the column. Fabrication of such an arrangement accurately without automated bending machine will be quite difficult. The manufacturing of such an inclined profile requires skilled labor and the still in some situations the 
builder need to compromise with the quality of output obtained.

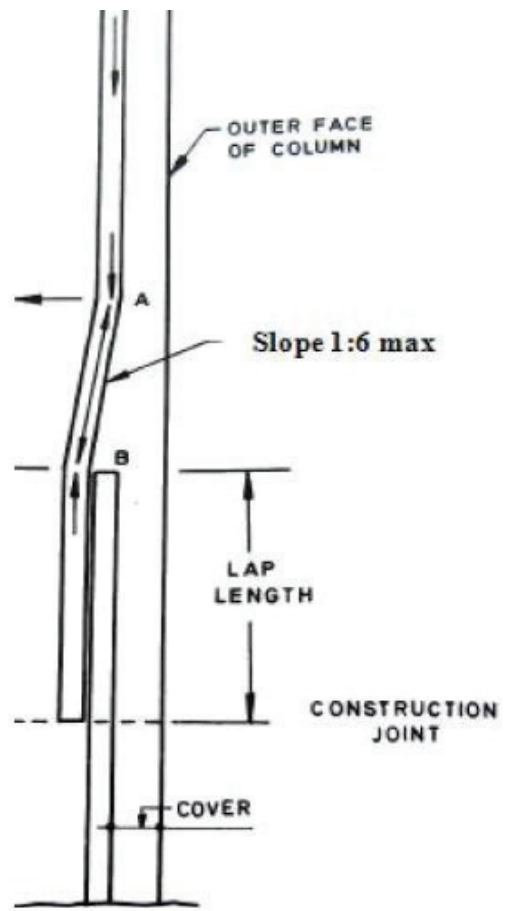

Figure 3. Profile of lapping

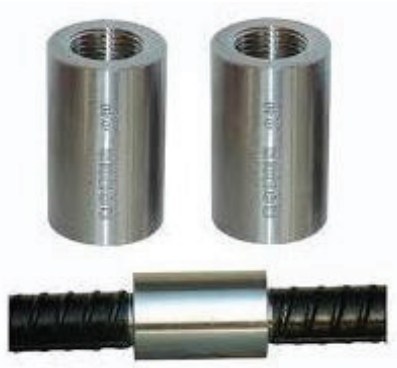

Figure 4. Profile of Mechanical coupler

The rebar coupler system (Fig 4) has the following advantages over conventional splicing system:

- Couplers are manufactured to have tensile strength greater than that of regular rebar.

- It helps in ensuring continuity of reinforcement bar for a span.

- The difficulties involved in staggered profile of reinforcement bar as required for traditional splicing can be avoided.

- Use of mechanical couplers enables reuse of formwork.

\section{LiterATURE REVIEW}

Damsara and Kulathunga have analysed the feasibility of using couplers instead of lap splices for reinforcement. Questionnaire survey, analysis of cost and tensile testing of specimens was the methodology adopted by the authors to achieve their objective. The economy of using rebar coupler was observed to be predominant for bars of larger diameter like 32 or $40 \mathrm{~mm}$. For the specimens tested, the failure was observed at yield point and in some specimens it was observed closer to ultimate load [1].

C. Neeladharan et.al has studied the behavior of mechanical coupler in reinforcement through experimental setup. coupler lengths of $3 \mathrm{~d}, 5 \mathrm{~d}$ and $8 \mathrm{~d}$, where ' $\mathrm{d}$ ' being diameter of rebar, were tested till failure using Universal Testing machine. The results of coupled system were compared to that of spliced system. The coupler length $3 \mathrm{~d}$ has given significant result compared to $5 \mathrm{~d}$ and $8 \mathrm{~d}$

Guan and Kwan have studied the role of rebar coupler in terms of improving the serviceability of structural members. Reinforced concrete specimens were tested for the slip behavior observed in mechanical couplers. It was concluded that the value of residual slip depends on gauge length and size of coupler [3].

Aryaebrahimpour and Barbara earles have studied the behavior of precast bridge columns consisting of coupled rebars replacing traditional reinforcement. Experimental data was used to prepare finite element models of selected bridges and the models were subjected to the seismic load of most active seismic location of the country. Under seismic conditions considered, the stresses in both the longitudinal reinforcing bars and the grouted coupler regions are found to be well within acceptable ranges [4].

\section{Methodology}

In present work the advantage of using couplers is explained with help of a case study on CVR Boys Hostel Mess building. The dimensions of the structure are $38 \mathrm{~m} \mathrm{x}$ $16 \mathrm{~m}$ with a storey height of $3 \mathrm{~m}$. The layout and positioning of columns are given in Fig. 5.

Total five different column sections i.e. $\mathrm{C} 1, \mathrm{C} 2, \mathrm{C} 3, \mathrm{C} 4$ and $\mathrm{C} 5$ were used in construction. The reinforcement details of the column type $\mathrm{C} 2$, column type $\mathrm{C} 4$ and column type $\mathrm{C} 5$ are given in fig. 6 , fig. 7 and fig. 8 respectively. The column sections $\mathrm{C} 1$ and $\mathrm{C} 3$ have same reinforcement details as that of $\mathrm{C} 2$ but are differentiated based on the type of footing provided. The comparative study was carried out estimating the cost of lap length and rebar coupler for columns in one floor. 


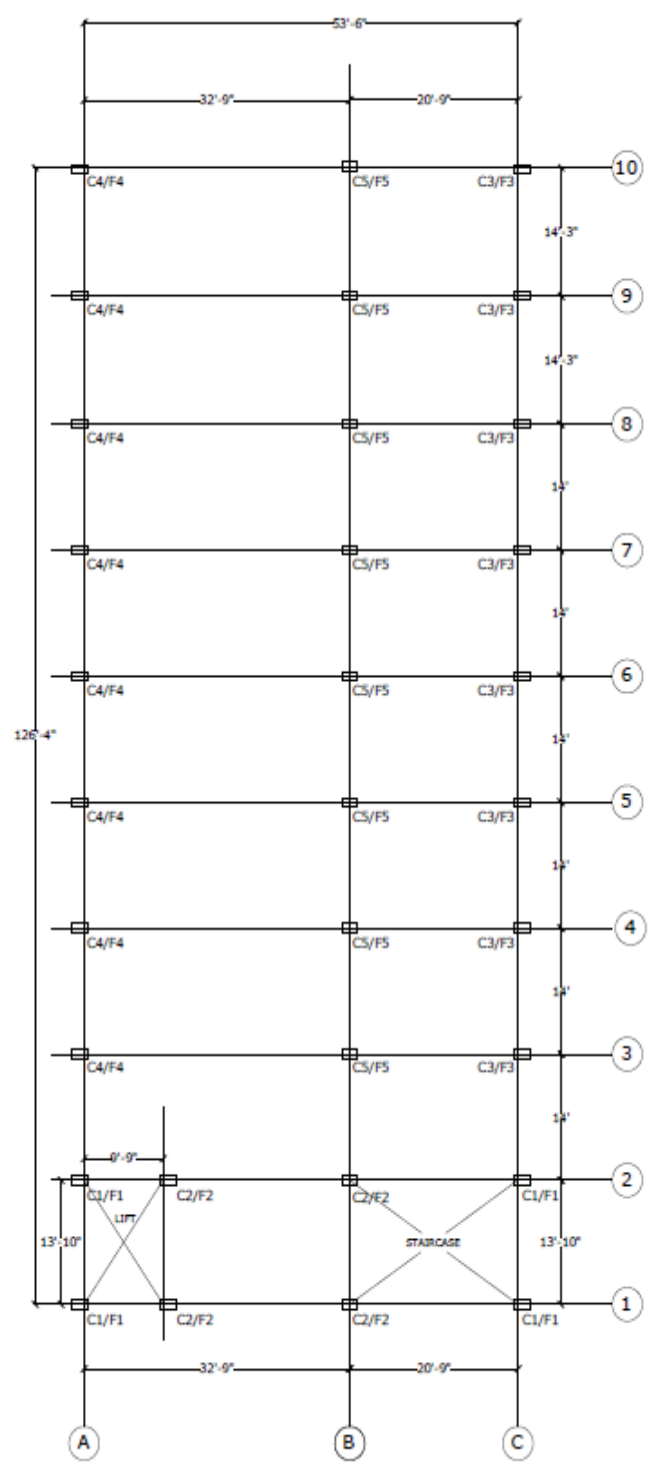

Figure 5. Boys Hostel Mess Centerline diagram

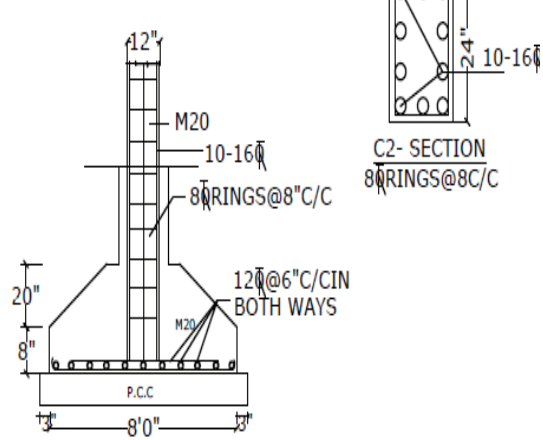

Figure 6. Reinforcement details of column type C2
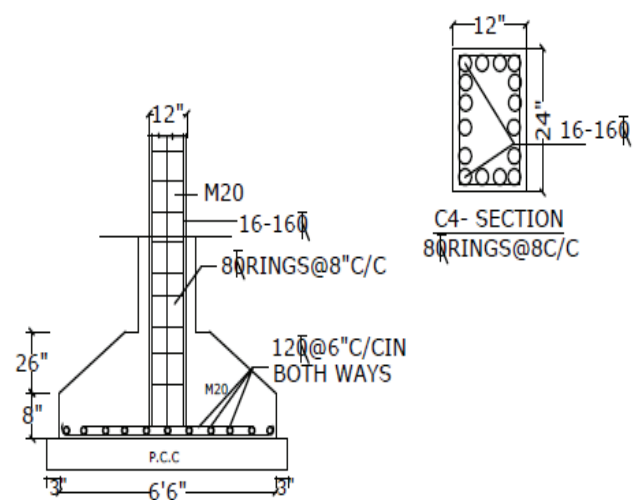

C4- SECTION 8ד्रRINGS@8C/C

Figure 7. Reinforcement details of column type C4

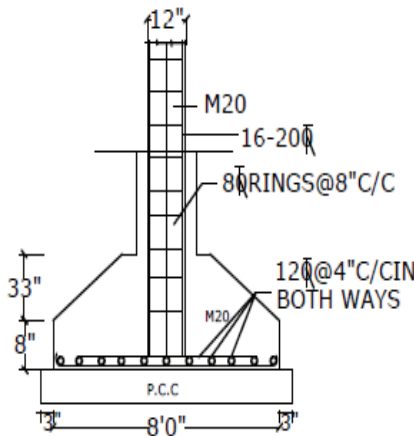

Figure 8. Reinforcement details of column type C5

Size of reinforcing bars used are $16 \mathrm{~mm}, 20 \mathrm{~mm}$ and $25 \mathrm{~mm}$. the type of couplers used are mechanical thread type couplers. The length of lap for reinforced concrete members can be calculated as specified in IS 456:2000 as

$$
L_{s}=48 \text { times diameter of bar }
$$

\section{ESTIMATION}

The value for one lap profile of reinforced bar was calculated as $36.8 \mathrm{~mm}, 10 \mathrm{~m}$ and $12 \mathrm{~m}$ for $16 \mathrm{~mm}, 20 \mathrm{~mm}$ and $25 \mathrm{~mm}$ diameter rebar respectively, using equation (i). The rate of reinforcement bar as per standard schedule of rates was taken as Rs. 58 for $16 \mathrm{~mm}$ and $20 \mathrm{~mm}$ bars. The rate for $25 \mathrm{~mm}$ bars is taken as Rs.52. The cost of coupler for $16 \mathrm{~mm}$ bar, $20 \mathrm{~mm}$ and $25 \mathrm{~mm}$ diameter bars is Rs.40, Rs.45 and Rs. 75 respectively.

Numbers of laps are 46, 10, and 10 for $16 \mathrm{~mm}, 20 \mathrm{~mm}$ and $25 \mathrm{~mm}$ diameter bars respectively. Table I gives the estimation for cost of lap length and Table II gives the details of estimation when mechanical couplers are used for one lap. The comparison in the cost when reinforced bars are lapped and when mechanical couplers are used is given in Table III. The cost comparison for lapping of bars and for use of mechanical couplers as replacement for all the bars in all the columns of one floor is given in Table IV. 
TABLE I.

ESTIMATION OF COST OF LAP LENGTH FOR ONE LAP

\begin{tabular}{|c|c|c|c|}
\hline $\begin{array}{c}\text { Diameter of Bar } \\
\text { (mm) }\end{array}$ & 16 & 20 & 25 \\
\hline $\begin{array}{c}\text { Length of Lap } \\
\text { a 50d } \\
\text { (m) }\end{array}$ & 0.800 & 1.000 & 1.250 \\
\hline $\begin{array}{c}\text { Length of bars } \\
\text { (m) }\end{array}$ & 36.80 & 10.00 & 12.50 \\
\hline $\begin{array}{c}\text { Weight of } \\
\text { bars/Rmt (kg) }\end{array}$ & 1.58 & 2.47 & 3.85 \\
\hline $\begin{array}{c}\text { Total Weight } \\
\text { (kg) }\end{array}$ & 58.144 & 20.470 & 48.125 \\
\hline $\begin{array}{c}\text { Rate of steel } \\
\text { reinforcement/kg } \\
\text { (in Rs) }\end{array}$ & 58 & 58 & 52 \\
\hline $\begin{array}{c}\text { Total Amount } \\
\text { (in Rs) }\end{array}$ & 3372 & 1169 & 2503 \\
\hline \multicolumn{2}{|c|}{}
\end{tabular}

TABLE II.

ESTIMATION OF COST OF COUPLERS FOR ONE LAP

\begin{tabular}{|c|c|c|c|}
\hline $\begin{array}{c}\text { Diameter of Bar } \\
\text { (mm) }\end{array}$ & 16 & 20 & 25 \\
\hline No. of Laps & 46 & 10 & 10 \\
\hline $\begin{array}{c}\text { Cost of coupler per } \\
\text { unit } \\
\text { (in Rs) }\end{array}$ & 40 & 45 & 75 \\
\hline $\begin{array}{c}\text { Total Amount } \\
\text { For couplers (in } \\
\text { Rs) (A) }\end{array}$ & 1840 & 450 & 750 \\
\hline $\begin{array}{c}\text { Minimum thread } \\
\text { Length }\end{array}$ & 55 & 75 & 90 \\
\hline $\begin{array}{c}\text { Price per } \\
\text { mm }\end{array}$ & 0.35 & 0.35 & 0.65 \\
\hline $\begin{array}{c}\text { Cost of threading } \\
\text { for one coupler }\end{array}$ & 19.25 & 26.25 & 58.5 \\
\hline $\begin{array}{c}\text { Total } \\
\text { Amount for } \\
\text { Threading(in Rs) } \\
\text { (B) }\end{array}$ & 885.5 & 262.5 & 585.0 \\
\hline $\begin{array}{c}\text { Total Amount (in } \\
\text { Rs) for coupler and } \\
\text { threading (A+B) }\end{array}$ & 2725.5 & 712.5 & 1335 \\
\hline
\end{tabular}

TABLE III.

COMPARISON BETWEEN COST OF LAP LENGTH AND COUPLER FOR ONE LAP

\begin{tabular}{|r|r|r|r|r|}
\hline S.No. & $\begin{array}{c}\text { Dia of } \\
\text { Bar } \\
(\mathbf{m m})\end{array}$ & $\begin{array}{c}\text { Cost of } \\
\text { Lap length } \\
\text { (in Rs) }\end{array}$ & $\begin{array}{c}\text { Cost of } \\
\text { Coupler } \\
\text { (in Rs) }\end{array}$ & $\begin{array}{c}\text { Difference } \\
\mathbf{( \% )}\end{array}$ \\
\hline 1 & 16 & 3372 & 2725.5 & $19.17 \%$ \\
\hline 2 & 20 & 1169 & 712.5 & $39.05 \%$ \\
\hline 3 & 25 & 2503 & 1335 & $46.64 \%$ \\
\hline \multicolumn{2}{|c|}{ Total } & 7044 & 4773 & $32.24 \%$ \\
\hline
\end{tabular}

TABLE IV.

COMPARISON BETWEEN COST OF LAP LENGTH AND COUPLER FOR COLUMNS IN ONE FLOOR

\begin{tabular}{|c|c|c|}
\hline $\begin{array}{c}\text { Diameter of Bar } \\
\text { (mm) }\end{array}$ & 16 & 20 \\
\hline No. of Columns (A) & 24 & 8 \\
\hline No. of Bars (B) & 26 & 16 \\
\hline $\begin{array}{c}\text { Cost of Lap (C) } \\
\text { (in Rs) }\end{array}$ & 3372 & 1169 \\
\hline $\begin{array}{c}\text { Cost of Couplers (D) } \\
\text { (in Rs) }\end{array}$ & 2725.5 & 712.5 \\
\hline $\begin{array}{c}\text { Cost of Lapping } \\
\left(\mathbf{A}^{*} \mathbf{B}^{* \mathbf{C})}\right. \\
\text { (in Rs) }\end{array}$ & $21,04,128$ & $1,49,632$ \\
\hline $\begin{array}{c}\text { Cost of Couplers } \\
\left(\mathbf{A}^{*} \mathbf{B} * \mathbf{D}\right) \\
\text { (in Rs) }\end{array}$ & $17,00,712$ & 91,200 \\
\hline $\begin{array}{c}\text { Difference (\%) } \\
\text { (\%) }\end{array}$ & 19.17 & 39.05 \\
\hline
\end{tabular}

Additionally, finite element analysis was performed using ANSYS 19.2 to find the strength of rebar coupler. $16 \mathrm{~mm}, 20 \mathrm{~mm}$ and $25 \mathrm{~mm}$ diameter bars with couplers were modeled and explicit dynamic analysis was performed to simulate the tensile testing of the specimen in UTM (Universal Testing Machine). The geometry, meshing and boundary conditions applied can be understood with help of fig 9, fig 10 and fig 11 respectively. Table $\mathrm{V}$ gives the details of the results obtained from finite element analysis in accordance with standard values as per IS 1786-1985.

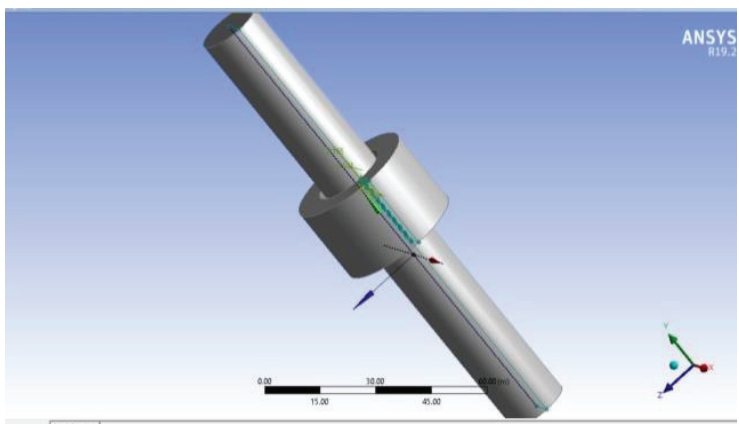

Figure 9. Geometry modeling of $16 \mathrm{~mm}$ rebar coupler in ANSYS Workbench

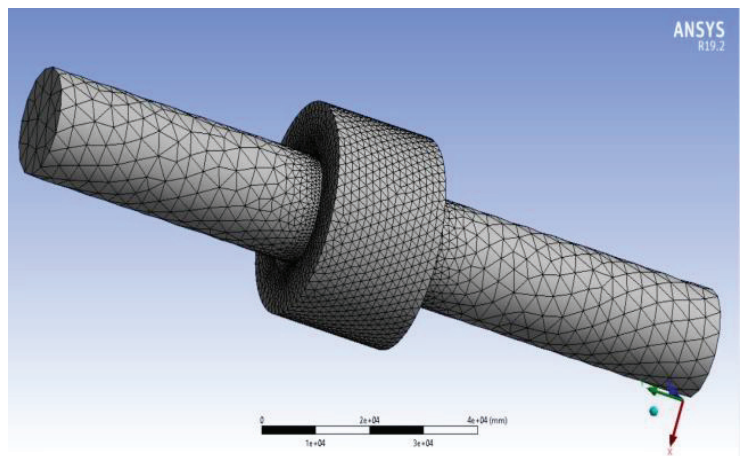

Figure 10. Meshing of $16 \mathrm{~mm}$ rebar coupler in ANSYS Workbench 


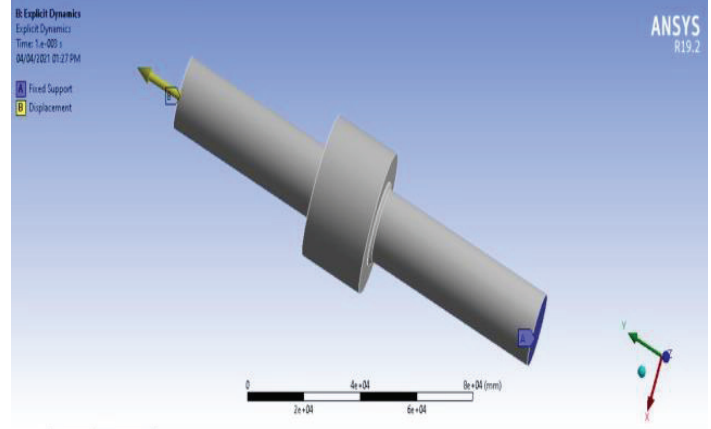

Figure 11:.Boundary Conditions of $16 \mathrm{~mm}$ rebar coupler in ANSYS Workbench

TABLE V.

COMPARISON BETWEEN COST OF LAP LENGTH AND COUPLER FOR COLUMNS IN ONE FLOOR

\begin{tabular}{|c|c|c|c|}
\hline Diameter of Bar (mm) & 16 & 20 & 25 \\
\hline Grade of Rebar & Fe 500 & Fe 500 & Fe 500 \\
\hline $\begin{array}{l}\text { Yield stress }\left(\mathrm{N} / \mathrm{mm}^{2}\right) \\
\text { (as per IS 1786-1985) }\end{array}$ & \multicolumn{3}{|c|}{$>500$} \\
\hline $\begin{array}{c}\text { Yield stress Obtained } \\
\left(\mathrm{N} / \mathrm{mm}^{2}\right)\end{array}$ & 531 & 549 & 556 \\
\hline $\begin{array}{l}\text { Ultimate stress( }\left(\mathrm{N} / \mathrm{mm}^{2} \text { ) }\right. \\
\text { (as per IS 1786-1985) }\end{array}$ & \multicolumn{3}{|c|}{$>545$} \\
\hline $\begin{array}{c}\text { Ultimate stress } \\
\text { Obtained } \\
\left(\mathbf{N} / \mathbf{m m}^{2}\right)\end{array}$ & 628 & 645 & 669 \\
\hline
\end{tabular}

\section{Conclusions}

1. The total amount for $16 \mathrm{~mm}$ diameter bar has been reduced by $45.43 \%$ when couplers are used instead of lap splices.

2. The difference in cost for $20 \mathrm{~mm}$ diameter bar was found to be $61.50 \%$

3. For $25 \mathrm{~mm}$ diameter the total difference was estimated as $70.03 \%$

4. The overall saving in the cost was estimated to be

5. 58\% when mechanical couplers are used instead of traditional method of lap splicing.

6. Considerable economy can be achieved for large diameter reinforcing bars such as $25 \mathrm{~mm}$.

7. When mechanical couplers are used for all the columns in one floor the difference in total cost is found to be $19.17 \%$ for $16 \mathrm{~mm}$ diameter bar and $39.05 \%$ for $20 \mathrm{~mm}$ diameter bar respectively.

8. The strength of coupled rebar was also found to significantly increase compared to the standard values specified.

9. The study concludes that couplers are an economic and effective replacement for traditional lap splice in column reinforcement.

\section{REFERENCES}

[1] Damsara and Kulathunga, 'Analysis of effectiveness of rebar couplers in splicing of reinforcement bars', International Conference on Advance in Civil and Environmental Engineering Practices for Sustainable Development (ACEPS2018), March 2018, University of Ruhuna.

[2] C. Neeladharan, ThouseefurRahma et.al, 'Behaviour of mechanical coupler in reinforcement", International Journal of Innovative Research inScience, Engineering and Technology Vol. 6, Issue 4, April 2017,pp. 6774-6781

[3] Guan and Kwan, 'Role of reinforcement couplers in serviceability performance ofconcrete members', IOP Conf. Series: Materials Science and Engineering, 2017.

[4] AryaEbrahimpour and Barbara Earles, 'Seismic behavior of Bridge Precast Columns with grouted rebar couplers', American Concrete Institute, Volume 341, 2020, pp. 188-201.

[5] R. H Singh and S.K.,Bhalla, " Reinforcement couplers as an alternatice to lap splices: A Case Study", International Journal of Engineering Research \& Technoogy, Vol. 2 Issue 2, February-2013

[6] Masonary Standards Joint Committee: Building Code Requirements for Masonary Structures, 2002.

[7] John W. Wallace, Headed Reinforcement a viable option, Concrete International, ACI, December 1997.

[8] Indian Standard Code of practice for design of Plain and Reinforced Concretes - IS 456-2000.

[9] Indian Standard code of practice for, High Strength deformed steel bars and wires for concrete reinforcement - IS 17861985. 